Article

\title{
When FIFA Rules the World: Hegemoni FIFA Terhadap Indonesia Dalam Kasus Pembekuan PSSI 2015-2016
}

\author{
Indra Kusumawardhana ${ }^{1}$, Arry Bainus ${ }^{2}$, Rusadi Kantaprawira ${ }^{3}$ \\ ${ }^{1}$ Ilmu Hubungan Internasional, Universitas Pertamina, Indonesia \\ ${ }^{2}$ Ilmu Hubungan Internasional, Universitas Padjadjaran Bandung, Indonesia \\ ${ }^{3}$ Ilmu Hubungan Internasional, Bakrie University, Indonesia
}

\section{SUBMISSION TRACK}

Recieved : :5 February, 2018

Final Revision :9 September 2018

Available Online: 30 November 2018

KEYWORD

FIFA, PSSI, Indonesia, Hegemony, Global Sport Governance.

\section{KATA KUNCI}

FIFA, PSSI, Indonesia, Hegemoni, Global Sport Governance

\section{CORRESPONDENCE}

Phone: 082231251204

E-mail: indra15008@mail.unpad.ac.id

\begin{abstract}
A $\quad$ B $\quad \mathbf{S}$ T $\mathbf{R}$ A $\mathbf{C}$ T
The bitter sanctions against the Indonesian Football Association (PSSI) by the Fédération Internationale de Football Association (FIFA) in 2015-2016 revealed an irritate reality regarding how weak the position of the state is; when dealing with organizations that are considered as representations of global institutions in the world of football. Therefore, Indonesia's powerlessness has made the question why the state is powerless before FIFA as an international organization finds its importance. Using the Coxian approach to understand the World Orders, this article argues that FIFA's hegemony supported by three main aspects, namely; first, the idea of football which is a populist sport, must be separated from the political intervention of state power. Second, FIFA's material capacity has made football as a sport with high economic value, even in Indonesia itself. Finally, supported by the previous two aspects, the governance of FIFA institutions has gripped various regions of the world, so that it has created hegemony superstructure in the world of football. Using critical analysis, the intellectual work of this paper does not only intend to improvise in the selection of topics but also presents alternative narratives in the contemporary constellation of contemporary international relations studies.
\end{abstract}

\section{A $\quad B \quad S \quad T \quad R \quad A \quad K$}

Kasus sanksi terhadap Persatuan Sepak Bola Seluruh Indonesia (PSSI) oleh The Fédération Internationale de Football Association (FIFA) pada tahun 2015-2016 telah mengungkap realitas pahit menyangkut betapa lemahnya posisi negara ketika berhadapan dengan organisasi yang dianggap sebagai representasi institusi global di dalam dunia sepak bola. Oleh karena itu, ketidakberdayaan Indonesia menjadikan pertanyaan mengapa negara tidak berdaya dihadapan FIFA sebagai sebuah organisasi internasional menemukan arti pentingnya. Menggunakan pendekatan Coxian dalam memahami World Orders, artikel ini berpendapat, hegemoni FIFA terhadap Indonesia berlandaskan pada tiga basis utama; pertama, ide terkait sepak bola yang merupakan olahraga populis, sehingga harus terlepas dari intervensi politik kekuasaan negara. Kedua, kapasitas material FIFA yang telah menjadikan sepak bola sebagai olahraga dengan nilai ekonomis yang tinggi, bahkan di Indonesia sendiri. Terakhir, ditopang oleh dua aspek sebelumnya, tata-kelola institusi FIFA telah mencengkram berbagai kawasan di dunia ini, sehingga 
Indra Kusumawardhana, Arry Bainus, Rusadi Kantaprawira| When FIFA Rules the World: Hegemoni FIFA Terhadap Indonesia Dalam Kasus Pembekuan PSSI 2015-2016

memunculkan superstruktur hegemoni di dalam dunia sepak bola. Menggunakan analisis kritis, kerja intelektual tulisan ini, tidak hanya bermaksud berimprovisasi dalam pemilihan topik namun juga menyajikan narasi alternatif di dalam konstelasi studi hubungan internasional kontemporer dewasa ini.

\section{Pendahuluan}

Pada 30 Mei 2015, Fédération Internationale de Football Association (FIFA) resmi menjatuhkan sanksi kepada Indonesia berupa larangan bertanding di turnamen Internasional serta larangan mendapatkan bantuan dari FIFA beserta Konfederasi Sepak Bola Asia (AFC), mencakup pemberhentian dana bantuan program atau kursus. Larangan ini, dijatuhkan tanpa batas waktu tertentu, hingga syarat-syarat yang diberikan oleh FIFA dipenuhi oleh PSSI dan Indonesia sendiri sebagai sebuah negara.

Sanksi ini berlandaskan pada justifikasi FIFA yang menganggap pemerintah Indonesia telah mengintervensi kegiatan PSSI selaku organisasi sepakbola nasional yang berada di bawah koordinasi FIFA selaku institusi global yang melarang adanya campur tangan pemerintah terhadap organisasi sepak bola pada aras nasional. Seperti yang terungkap dalam pernyataan berikut "FIFA's decision "resulted from the effective 'take over' of the activities of PSSI (the Indonesian football association) by the Indonesian authorities," dan oleh karenanya, "All Indonesian national teams (national or club) are prohibited from having international sporting contact which includes participating in FIFA and AFC competitions".

Menyikapi kejadian ini, rakyat Indonesia terusik, dikarenakan publik harus

\footnotetext{
${ }^{1}$ Seperti yang termuat di dalam sumber media online

http://www.channelnewsasia.com/news/sport/foo tball-fifa-suspends/1882540.html diakses pada tanggal 26 Desember 2015 pukul 00.00 WIB
}

menghadapi kenyataan Tim Nasional sepak bola Indonesia tidak berlaga di panggung internasional, bahkan organisasi yang menaungi seluruh organisme sepak bola di bumi pertiwi akan terancam mati-suri sampai FIFA mencabut sanksi yang diberikan kala itu. Sedangkan selama ini, sepak bola telah dianggap sebagai sebuah Fiesta rakyat yang memiliki basis pendukung luar biasa besar di Indonesia.

Hal ini memunculkan amarah publik yang menuduh KEMENPORA melakukan intervensi terhadap PSSI, terutama merujuk pada Statuta FIFA yang melarang campur tangan negara di dalam organisasi sepak bola nasional untuk menjalankan tugasnya sebagai anggota FIFA. Lebih jauh lagi publik menjustifikasi seluruh drama KEMENPORA versus PSSI ini merupakan sebuah drama politik kekuasaan yang sedang dilancarkan oleh rezim yang berkuasa, serta menuntut untuk KEMENPORA segera mencabut sanksi kepada PSSI. $^{2}$ Seluruh prosesnya semakin di dramatisasi dan menjadi sebuah santapan publik yang hanya bisa menerka nerka kausalitas dari permasalahan yang terjadi.

2 Septi, Amalia. 2015. "Gelar Demonstrasi, Jakmania Minta Menpora Cabut SK Pembekuan PSSI". Diakses secara daring pada halaman https://sport.detik.com/sepakbola/ligaindonesia/2988856/gelar-demonstrasi-jakmaniaminta-menpora-cabut-sk-pembekuan-pssi pada tanggal 19 Agustus 2018 pukul $00.00 \mathrm{WIB}$ 
Indra Kusumawardhana, Arry Bainus, Rusadi Kantaprawira| When FIFA Rules the World: Hegemoni FIFA Terhadap Indonesia Dalam Kasus Pembekuan PSSI 2015-2016

Setidaknya, terdapat 3 (tiga) tulisan yang telah membahas permasalahan antara Indonesia, PSSI, dan FIFA. Pertama, tulisan Khrisna Ariyanto bertajuk "Analyzing the Conflict between Football Organizations in Indonesia" fokus pada dinamika permasalahan antara FIFA, Indonesia, PSSI, dan Komite Penyelamatan Sepak Bola Indonesia (KPSI) yang terjadi sejak tahun 2011.3 Menggunakan Drama Theory dan Graph Model for Conflict Resolution, artikel ini menjelaskan dinamika konflik yang terjadi, tulisan ini memberikan gambaran pola-pola yang terjadi di dalam konflik antar aktor dalam kasus yang diangkat.

Kedua, tulisan yang secara spesifik membahas tentang kasus sanksi yang dijatuhkan oleh FIFA kepada Indonesia ditulis oleh Indra Kusumawardhana dan Muhammad Badarrudin. Tulisan dengan tajuk "FIFA and Sport Sovereignty: Analyzing the Triangular Relationship among the FIFA, Kemenpora RI, and the PSSI" telah mengungkap cara-cara FIFA menegasikan kedaulatan negara untuk menegakkan kedaulatan sepak bola di dalam sistem internasional. ${ }^{4}$ Adapun, tulisan ketiga, ditulis oleh Tibortius Melkior Saceira dengan judul "Diplomasi Indonesia Dalam Mengakhiri Sanksi FIFA Tahun 2015", menghadirkan konsep diplomasi tulisan ini mengklaim bahwasanya Indonesia

\footnotetext{
3 Ariyanto, Khrisna. "Analyzing the Conflict between Football Organizations in Indonesia." Procedia-Social and Behavioral Sciences 115 (2014): 430-435.

4 Kusumawardhana, Indra dan Muhammad Baddarudin. "FIFA and Sport Sovereignty: Analyzing the Triangular Relationship among the FIFA, Kemenpora RI, and the PSSI." Proceeding Re-examining Governance: Strengthening Citizenship in The Changing World (2016): 237
}

menggunakan pendekatan Multi-track Diplomacy dalam meretas solusi dalam menghadapi sanksi yang dijatuhkan oleh FIFA. ${ }^{5}$

Bertolak dari pustaka terdahulu di atas, jika kebanyakan tulisan-tulisan yang ada fokus pada upaya menjawab pertanyaan "How" atau "How could" di dalam dinamika permasalahan yang terjadi. Tulisan ini fokus kepada pertanyaan "Why" dalam mengungkap hegemoni FIFA terhadap Indonesia selaku negara yang memiliki kedaulatan dengan sebuah organisasi yang merepresentasikan global sport governance. Oleh karenanya, pertanyaan sentral yang akan disasar oleh artikel ini adalah mengapa negara, dalam konteks ini Indonesia, tidak berdaya menghadapi FIFA sebagai sebuah organisasi yang mengelola sepak bola dunia? Menggunakan pendekatan Coxian yang menyinggung tentang super-struktur dari hegemoni dari tatanan dunia (world orders), artikel ini mengklaim bahwasanya ketidakberdayaan Indonesia bersumber pada hegemoni FIFA telah berhasil menegakkan dominasi terselubung sebagai Organisasi Internasional non-negara yang mempunyai sport sovereignty.

Adapun hegemoni FIFA, menurut artikel ini, ditopang oleh popularitas sepakbola yang merepresentasikan ide olah raga universal, kapasitas material FIFA dalam menopang aktifitas sepakbola dunia, dan institusi-institusi yang berada di dalam koordinasi FIFA. Kekuatan FIFA dengan menggunakan popularitas sepak bola menjadi

5 Saceira, Tibortius. “"Diplomasi Indonesia Dalam Mengakhiri Sanksi FIFA Tahun 2015". eJournal Ilmu Hubungan Internasional, 2018, 6 (1) $095-108$ 
Indra Kusumawardhana, Arry Bainus, Rusadi Kantaprawira| When FIFA Rules the World: Hegemoni FIFA Terhadap Indonesia Dalam Kasus Pembekuan PSSI 2015-2016

tantangan nyata terhadap post-westphalian model dengan menerobos batas - batas kedaulatan negara - bangsa dalam hal ini menculik salah satu cabang olah raga yakni sepak bola dari Domestic Soverignty sebuah negara serta melemahkan kapasitas negara dalam mengatur pranata domestik dalam kedaulatannya.

\section{Metode Penelitian}

Penelitian ini merupakan penelitian deskriptif menggunakan pendekatan kualitatif. Metode kualitatif dianggap menjadi pilihan terbaik ketika mengkaji kehidupan manusia untuk kasus-kasus terbatas, sifatnya kasuistik dan kontekstual namun mendalam (in depth) dan bersifat total atau menyeluruh (holistic), dalam arti tidak mengedepankan pemilahan-pemilahan gejala secara konseptual ke dalam aspek-aspeknya yang eksklusif dan terisolir. Siapa pun yang terlibat dalam bentuk penelitian ini harus menerapkan cara pandang penelitian yang bersifat induktif, berfokus terhadap makna individual dan menerjemahkan kompleksitas sebuah situasi.

Teknik pengumpulan data menggunakan upaya mengumpulan data sekunder. Data sekunder diperoleh dari bahan hukum primer yang difokuskan kepada bahan-bahan studi dokumen atau kepustakaan seperti buku, majalah, dokumen resmi dari FIFA, makalah-makalah, jurnal, artikel-artikel, surat kabar serta situs-situs internet yang berkaitan dengan objek yang ditulis. kepustakaan berupa, literatur terkait seperti naskah ilmiah, media massa, laporan penelitian serta dokumen yang relevan.

Seperti yang telah dinyatakan sebelumnya; tulisan ini akan mengkaji varian dari institusi global yang belum banyak mendapat perhatian yakni FIFA. Salah satu konsep yang tersedia untuk memahami keberadaan FIFA adalah dengan mengkaitkannya sebagai Global Private Governance yang telah begitu lama eksis di dalam sistem internasional. Global Private Governance (GPG) secara umum dipandang sebagai sebuah fenomena baru yang sarat dengan nuansa globalisasi neo-liberal. ${ }^{6}$ Walaupun, baik international Olympic Commitee (IOC) yang didirikan tahun 1894 dan International Federation of Association Football (FIFA) yang didirikan pada tahun 1904 jauh lebih tua dari semua institusi institusi intergovernmental yang telah banyak menjadi kajian dalam studi hubungan internasional pasca Perang Dunia Ke-II dan kajian - kajian globalisasi kontemporer. Bahkan, realitas menunjukan bahwa olah raga internasional memiliki rezim pemerintahan yang canggih hingga mampu mempertahankan klaim absolut berkaitan dengan sifat otonom dari seluruh hukum hukum negara dan otoritas publik. ${ }^{7}$ "The character of global sport law as transnational autonomous order created by the private global institutions has inspired legal scholars to compare the lex sportiva to the lex mercatoria". 8

Menurut tulisan ini, melemahnya otoritas negara dalam kasus FIFA sangat relevan jika dilihat dari sudut pandang ini.

\footnotetext{
${ }^{6}$ Dingwerth, Klaus and Philipp Pattberg. 2006. 'Global Governance as Perspective on World Politics.'Global Governance 12(2), 185-203.

${ }^{7}$ Chappelet, Jean Loup. Autonomy of Sport in Europe. 2010. Strasbourg: Council of Europe Publishing.

${ }^{8}$ Foster, Ken. "Is there a global sports law." Ent. L. 2 (2003): 2
} 
Indra Kusumawardhana, Arry Bainus, Rusadi Kantaprawira| When FIFA Rules the World: Hegemoni FIFA Terhadap Indonesia Dalam Kasus Pembekuan PSSI 2015-2016

Dikarenakan FIFA memiliki kecanggihan postur pemerintahan yang jauh dari sekedar investasi yang dilakukan para perusahaan trans-nasional sekalipun. Terutama dalam kasus sepak bola sebagai representasi kultur dan ekonomi global yang mempunyai otoritas yang bersifat global seperti FIFA, negara memiliki tantangan dikarenakan FIFA mengatur aktivitas yang sangat spesifik dan menyangkut kegemaran rakyat yang berada di dalam kotak kedaulatan yang melingkupinya. Preferensi dari warga dunia yang sangat menggemari sepak bola sebagai olah raga dapat kita takar hanya dari satu kalimat berikut "With more than 200-member associations the Fédération Internationale de Football Association (FIFA) is one of the largest nonprofit organizations in the world". 9

Secara kritis, tulisan ini melihat bahwasanya postur FIFA sebagai satusatunya organisasi global yang mengatur sepakbola, menjadikannya sangat berkuasa untuk dapat mengatur olahraga yang memiliki basis penggemar yang sangat luar biasa luas ini. Oleh karenanya, konsep hegemoni menjadi penting dalam kaitan membahas kekuasaan FIFA di dalam sistem internasional, terutama dalam konteks menjawab keingintahuan seputar ketidakberdayaan negara menghadapi FIFA.

Konsep hegemoni di dalam studi hubungan internasional dihadirkan oleh Robert Cox selaku pioneer pendekatan kritis di dalam Hubungan Internasional dengan meminjam buah pemikiran progresif Gramsci seorang Marxis Italia. Karya - karya

${ }^{9}$ Eick, Volker. "A neoliberal sports event? FIFA from the Estadio Nacional to the fan mile." City 14, no. 3 (2010): 278-297. progresif Gramsci yang terserak di dalam berbagai catatan penjara ketika menjadi tahanan politik di bawah rezim Mussolini telah memberikan ilham terhadap cendekia ilmu sosial setelah Zamannya, termasuk Cox yang menggunakannya sebagai batu loncatan dalam memahami hegemoni di dalam sistem internasional. Oleh karenanya, memahami pemikiran Gramsci sangat penting sebagai pintu masuk pendekatan tulisan ini. Hegemoni di dalam pemikiran Gramsci digambarkan sebagai "hegemony rests on the ability of a dominant class to form a consensual relationship with subaltern classes through a variety of social and cultural channels. ${ }^{10}$ Dalam perspektif ini, kekuasaan dikonstruksikan bukan melalui koersi, kekerasan, ataupun paksaan, melainkan dengan menggunakan konsensus dan kontrol. ${ }^{11}$

Kerja intelektual Cox beranjak lebih jauh dalam mengelaborasikan konsep Gramsci tentang basis struktur dan superstruktur, dalam upaya kritisnya meretas pendekatan alternatif di dalam teori hubungan internasional. Cox memainkan fleksibilitas pemahaman Gramsci tentang relasi kekuasaan di dalam masyarakat domestik dengan mengangkat level of analysis-nya untuk menelaah relasi kekuasaan di dalam sistem internasional. Robert Cox menggambarkan hegemoni sebagai suatu manifestasi struktur sosial,

${ }^{10}$ Gramsci, Antonio. Selections from the Prison Notebooks of Antonio Gramsci: Ed. and Transl. by Quintin Hoare and Geoffrey Nowell Smith. Eds. Geoffrey Nowell-Smith, and Quintin Hoare. International Publishers, 1971. (55-60, 415-25)

${ }_{11}$ Sugiono, Muhadi. "Kritik Antonio Gramsci terhadap pembangunan dunia ketiga". Pustaka Pelajar. 1999. Hal.35 
Indra Kusumawardhana, Arry Bainus, Rusadi Kantaprawira| When FIFA Rules the World: Hegemoni FIFA Terhadap Indonesia Dalam Kasus Pembekuan PSSI 2015-2016

ekonomi, dan politik yang diekspresikan dalam bentuk norma-norma universal, institusi-institusi, dan mekanismemekanisme yang mendasari aturan dan tingkah laku negara serta civil society yang melampaui batas-batas nasional - suatu tatanan yang menopang mode produksi yang dominan. ${ }^{12}$

\section{Gambar.1: Three Categories of Forces}

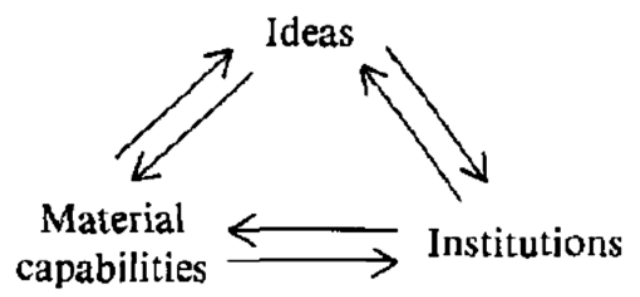

Dalam konteks menciptakan tatanan, menurut Cox ada tiga macam kekuatan yang berinteraksi di dalam struktur yang disinggung oleh Gramsci yakni kapasitas material, ide, dan institusi - institusi. Dimana hegemoni menuntut ketiganya berinteraksi secara resiprokal dalam mengartikulasikan potensi - potensi untuk melakukan rekonfigurasi kekuatan sosial "......a fit between material power, ideology and institutions, hegemony may seem to lend itself to a cyclical theory of history; the three dimensions fitting together in certain times and places and coming apart in others". Penekanan terhadap sifat interaksinya yang berpola serupa siklus di dalam sejarah menjadikan aspek - aspek tersebut tidak memiliki sistematika yang kaku namun lebih bersifat lentur dan interaktif saling mempengaruhi secara resiprokal.

Dimensi pertama yang dicermati oleh tulisan ini adalah Institusionalisasi, dimana

12 Hadiwinata, B. S., 2002. Politik Bisnis Internasional. Kanisius. Hal. 47 aktus institusionalisasi dalam pemahaman politik merupakan alat untuk melakukan stabilisasi, penyelarasan dan pelanggengan sebuah tatanan sosial. Menurut Cox (1981) "Institutions reflect the power relations prevailing at their point of origin and tend, at least initially, to encourage collective images consistent with these power relations". Dimana di dalam pemahaman kritis tulisan ini, institusi selalu memiliki kecenderungan politis dikarenakan ketidakberdayaannya terhadap relasi kekuasaan antar aktor yang menjadi entitas politik di dalamnya. Karena institusi menyediakan kanal-kanal untuk mengatur konflik - konflik internal bahkan Sumber: Cox, Robert W. "Social forces, states and world orders: beyond international out relations theory." Millennium 10, no. 2 (1981): cut Institutions may become the anchor for such a hegemonic strategy since they lend themselves both to the representations of diverse interests and to the universalisation of policy". ${ }^{13}$ Trajektori tata kelola sepak bola dunia yang telah lama diinstitusionalisasikan di bawah keberadaan FIFA menemukan relevansinya dengan pandangan ini, sehingga keberadaanya tidak bisa dipisahkan dengan potensi munculnya hegemoni etis di berbagai agenda yang dipromosikannya.

Kemudian "Kapasitas Material" (Material Capabilities) menjadi dimensi ketiga yang menopang hegemoni FIFA, dimana menurut Cox memainkan peran potensi - potensi destruktif dan produktif. Seperti yang dijelaskan oleh Cox sebagai berikut "In their dynamic form these exist as technological and organisational

13 Cox, Robert W. "Social forces, states and world orders: beyond international relations theory." Millennium 10, no. 2 (1981): 137. 
Indra Kusumawardhana, Arry Bainus, Rusadi Kantaprawira| When FIFA Rules the World: Hegemoni FIFA Terhadap Indonesia Dalam Kasus Pembekuan PSSI 2015-2016

capabilities, and in their accumulated forms as natural resources which technology can transform, stock equipment (e.g industries and armaments), and the wealth which can command these". Menurut pemahaman tulisan ini, di dalam wujudnya yang dinamis, ada tiga aspek penting dalam memahami artikulasi dari kapasitas material dari kekuatan-kekuatan sosial di dalam struktur hegemon yakni kapasitas organisatoris, penggalangan dana secara ekstensif, dan penguasaan teknologi di ranah praktis dapat menjadi instrumen untuk mengkonsolidasikan konsensus antar aktor di dalam sistem internasional (Baik aktor negara maupun non-negara).

Dimensi kekuatan ide menjadi konsep ketiga dalam tulisan ini; kekuatan ide berdasarkan penjelasan Cox, memuat dua bentuk; intersubjektif dan kolektif. Pertama, ide yang memainkan peran sebagai kekuatan intersubjektif di dalam benak antar aktor, dimana makna - makna intersubjektif yang direproduksi aktor di dalam interaksinya berperan sebagai makna bersama yang melandasi hakekat alami hubungan antar aktor di dalam sistem internasional. Keberadaan makna bersama sangat penting adanya, karena mampu memunculkan semacam ekspektasi dan pola hubungan yang dianggap wajar dari prilaku aktor di dalam sistem sosial. Sedangkan bentuk kedua dari ide, memainkan peran untuk memunculkan citra bersama (Collective Images) yang dipatuhi sebagai sebuah tatanan di dalam sistem sosial. Dimana keberadaannya memberikan pemahaman terhadap aktor terkait the nature and the legitimacy of prevailing power relations, the meanings of justice and public good, and so forth. ${ }^{14}$

\section{Hasil dan Pembahasan \\ Tata Kelola FIFA Sebagai Institusi Global}

Sepak Bola telah menjadi cabang olah raga yang paling populer di dunia, setidaknya realitas ini terjadi sejak akhir abad kesembilan belas dimana sepak bola digaungkan dalam tataran internasional oleh Inggris. Sepak Bola menjadi permainan yang mendunia yang berkembang secara kultural diberbagai komunitas sosial seluruh kontinen dunia. ${ }^{15}$

Menariknya, hingga saat ini, di dalam dunia sepak bola hanya mengenal satu organisasi internasional yang mempunyai wewenang untuk mengatur hal - hal yang berkaitan dengan sepak bola yakni FIFA baik dalam tataran global, regional bahkan nasional; mengacu pada realitas ini FIFA dapat dikatakan sebagai representasi dari Global Governance dalam sepak bola. Keberadaanya menjadi akar tunjang untuk berlangsungnya olah raga yang dapat dianggap hiburan paling massal di dunia. Menurut Cox, an international organization 'functions as a process through which the institutions of hegemony and its ideology are developed'. ${ }^{16}$ Sehingga keberadaan FIFA sebagai organisasi satu-satunya yang menaungi seluruh organisme institusi

${ }^{14}$ Cox, Robert W. "Social forces, states and world orders: beyond international relations theory." Millennium 10, no. 2 (1981): 136.

15 Giulianotti, Richard, ed. Sport and modern social theorists. Hampshire: Palgrave Macmillan, 2004.

16 Cox, Robert W., and Timothy J. Sinclair. Approaches to world order. No. 40. Cambridge University Press, 1996. 139 
Indra Kusumawardhana, Arry Bainus, Rusadi Kantaprawira| When FIFA Rules the World: Hegemoni FIFA Terhadap Indonesia Dalam Kasus Pembekuan PSSI 2015-2016

sepakbola dunia baik pada tataran regional maupun nasional dapat dikatakan menjadi representasi penting dari pendapat Cox tersebut. Meskipun Cox sendiri, tidak membahas FIFA sebagai diskursus inti dari teorisasi yang Cox lakukan.

Keunikan dari pemerintahan yang dilakukan oleh FIFA merupakan ujud dari keinginan untuk melakukan monopoli terhadap olah raga. Setiap pihak yang berkepentingan di dalam olah raga internasional baik itu atlet, federasi olah raga, konsumen hiburan olah raga, otoritas publik dan kepentingan komersil mendapatkan keuntungan yang signifikan dari kompetisi yang digulirkan oleh pemerintahan global olah raga yang menderas hingga level nasional tiap - tiap negara anggota. ${ }^{17}$

Namun, kompetisi yang baik menuntut peraturan yang stabil dan jelas serta konsisten, dimana hal ini hanya bisa dilakukan dengan maksimal melalui monopoli regulasi itulah FIFA dengan statuta-nya. ${ }^{18}$ Kontribusi unik yang tidak tergantikan ini telah berlangsung sangat lama bahkan semakin menguat setelah FIFA dalam era kepemimpinan Joao Havelange (1974) melebarkan sayapnya kepada negara - negara yang baru muncul pasca perang dunia kedua. Seperti yang diungkap oleh Bill Crane dalam tulisannya "How FIFA ruined Soccer".

FIFA as it exists today is the creation of its last president, João Havelange, who unseated Stanley Rous, long known for

\footnotetext{
${ }^{17}$ Neale, Walter C. "The peculiar economics of professional sports: A contribution to the theory of the firm in sporting competition and in market competition." The Quarterly Journal of Economics (1964): 1-14.

${ }_{18}$ Scully, Gerald W. The market structure of sports. University of Chicago Press, 1995.
}

\begin{abstract}
supporting apartheid soccer teams. After coming to power in 1974, Havelange presided over FIFA's transformation into a fully corporate structure, financed by sponsorship deals rather than contributions from national and regional federations. Under Havelange FIFA executed an unprecedented turn toward the nations of the Global South, which it had previously ignored but who were now international soccer's fan base. But the turn wasn't an inclusive gesture. It was designed to capitalize on business opportunities in rapidly growing countries like Mexico - where Havelange's associates were accused of bribery in connection with the 1992 World Cup and future Olympic games and Brazil, where Swiss authorities estimated Havelange himself took over $\$ 50$ million in bribes during the 1990s. ${ }^{19}$
\end{abstract}

Kepedulian FIFA yang sebelumnya bisa dikatakan merupakan simbol dari kekuatan imperium kolonial akhirnya menunggangi kesempatan yang ditawarkan oleh Globalisasi dalam mengakumulasikan kapital melalui ekspansi pasar yang sebelumnya hanya berpusat pada tangkai - tangkai ekonomi benua biru eropa menuju seluruh dunia. Perubahan ini terakomodasi dengan adanya momentum dekolonialisasi pasca Perang Dunia II yang memunculkan negara negara baru yang terbentuk pasca bangkitnya gelombang nasionalisme melawan Imperialisme kolonial. Meskipun banyak yang mengkritik kepentingan kapitalis yang dibawa oleh FIFA, namun indahnya sepak bola masih menjadi sebuah tawaran yang

$19 \quad$ Dikutip dari media online
https://www.jacobinmag.com/2015/06/sepp-
blatter-world-cup-qatar-charges/. Diakses pada
05 Januari 2016 pukul 11.00


Indra Kusumawardhana, Arry Bainus, Rusadi Kantaprawira| When FIFA Rules the World: Hegemoni FIFA Terhadap Indonesia Dalam Kasus Pembekuan PSSI 2015-2016

sulit untuk ditolak oleh negara - negara yang mempunyai gairah sepak bola nasional. Terlebih lagi berbagai agenda FIFA di dalam rentang sejarah selalu ditopang oleh perusahaan-perusahaan besar yang menjadi partnernya, hal ini seperti yang telah disinggung oleh John Sugden dan Alan Tomlinson yang menyatakan bahwasanya pada saat Havelange's campaign was heavily supported by TNCs because his agenda implied a commercialization of international football. $^{20}$

\section{Gambar. $1^{21}$}

Tata Kelola Organisasi FIFA

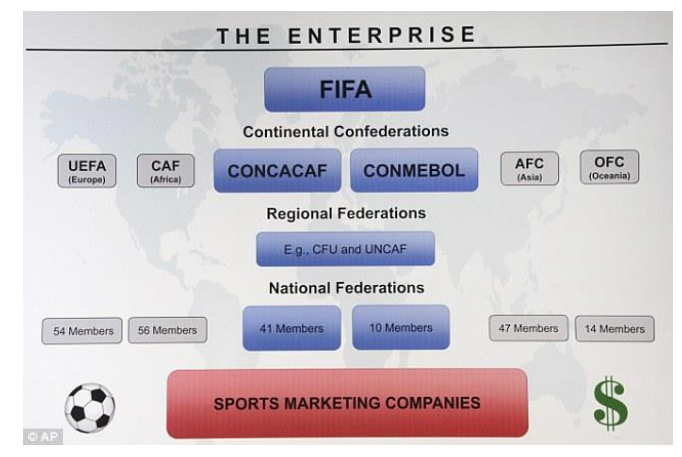

Melirik pranata FIFA secara makro; FIFA selama ini membangun tata kelola organisasinya dalam kerangka tata kelola lintas - batas yang dibagi berdasarkan kontinen di dunia ini. FIFA menggunakan pendekatan ini untuk mengatur dan mengawasi aktivitas organisasi sepak bola di tataran nasional pemerintahan negara. Tidak ada negara-bangsa yang boleh

\footnotetext{
${ }^{20}$ Sugden, John dan Alan Tomlinson. FIFA and the Contest for World Football: Who rules the People's Game? Cambridge: Polity.1998b,

${ }^{21}$ Dapat diunduh secara online pada halaman online

https://www.baselgovernance.org/sites/collective. localhost/files/documents/igc/first_report_by_igc to_fifa_exco.pdf. Terakhir akses 20 Agustus 2018.
}

mengintervensi kedaulatan imajiner yang dibangun oleh FIFA dalam kerangka Global Governance sepak bola yang dibangun oleh FIFA sendiri. Statuta FIFA menjadi aturan main yang memperkuat legitimasi FIFA dalam mengatur negara-bangsa dalam hal sepak bola.

Hierarki organisasi di gambar diatas menunjukan tata-kelola lintas batas yang terkantong - kantongkan secara kontinental, regional dan nasional, menjadikan FIFA mempunyai kekuatan untuk menarik seluruh aktor-negara yang ingin memenuhi kebutuhan rakyatnya untuk menikmati cantiknya sebuah permainan sepak bola yang disuguhkan oleh tim sepak bola domestik dalam negeri maupun tim nasional yang menjadi wakil dalam kompetisi internasional yang digagas oleh FIFA dan seluruh institusi perwakilannya yang bersifat lintas - batas negara.

PSSI sebagai organisasi sepakbola nasional Indonesia, sejak berdiri pada tahun 1930, kemudian bergabung dengan FIFA pada 1 November 1952. Menjadi anggota Asian Footbal Confederation (AFC) sebagai organisasi regional di bawah tata kelola FIFA yang menaungi di tataran lebih luas. ${ }^{22}$ Oleh karenanya, berbagai ajang kompetisi di tataran internasional yang diikuti oleh Indonesia berada di dalam kekuasaan FIFA sebagai organisasi yang menaungi seluruh organisasi regional sepakbola dunia.

22 Pssi.or.id. "Sejarah PSSI". Diakses secara online pada halaman http://www.pssi.or.id/dev/page/detail/5/SejarahPSSI. Terakhir akses pada 19 Agustus 2018. 
Indra Kusumawardhana, Arry Bainus, Rusadi Kantaprawira| When FIFA Rules the World: Hegemoni FIFA Terhadap Indonesia Dalam Kasus Pembekuan PSSI 2015-2016

\section{Kapasitas Material FIFA Sebagai} Representasi Global Sport Governance

Namun dalam hal ini, dapat dikatakan landasan dari postur pemerintahan FIFA sebagai aktor non- negara yang bersifat lintas-batas teritori negara-bangsa mempunyai dua modalitas yakni satu kekuatan sepak bola sebagai olah raga yang mendunia kemudian kekuatan kapital yang didukung oleh pihak - pihak yang ingin mengambil keuntungan dari kompetisi sepak bola yang digulirkan oleh negara - negara anggota FIFA. Dua kekuatan ini menjadi keunikan FIFA dalam memaksakan peraturannya terhadap negara - negara yang ingin mempunyai tim sepak bola yang diakui oleh dunia internasional. Sebuah organisasi internasional non-negara yang sangat canggih mampu lepas dari kaca mata kritis publik yang tidak dapat melihat sifat dari otoritas FIFA dalam sistem internasional.

Kekuatan kapital yang didukung oleh sponsor perusahaan - perusahaan multinasional besar memuluskan proses komersialisasi sepak bola yang dilakukan FIFA serta menyokong kekuatan politik FIFA dalam melegitimasi otoritasnya yang bersifat otonom terhadap negara - negara yang memiliki liga - liga dalam tataran nasional serta tim nasional sebagai representasi dari kebanggaan nasional.

However, commercialization has further increased FIFA's importance as an arena of identity politics. Not only has FIFA's membership experienced a massive growth; improved revenues have also enabled

\section{FIFA to grant substantial development aid. $^{23}$}

Terlebih lagi, sepak bola di bawah komando FIFA telah berkembang menjadi bisnis raksasa yang melibatkan jutaan manusia baik sebagai target pasar maupun aktor-aktor yang terlibat langsung dalam tata kelola sepak bola dunia. Setidaknya gambaran tersebut dapat dilihat dari grafik di bawah ini.

\section{Grafik.1}

FIFA Revenue 2015-2018 (Outlook) $)^{24}$

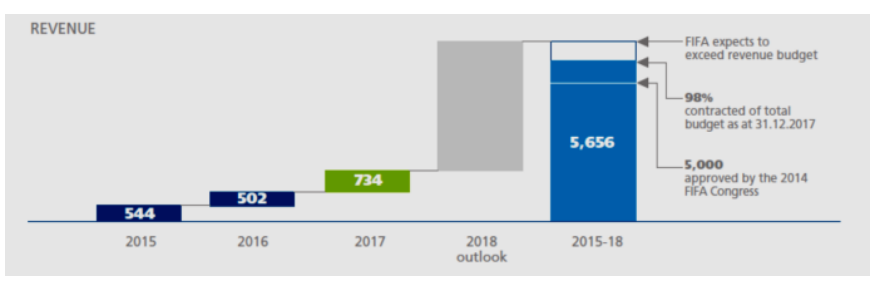

Berdasarkan grafik.1, dapat dilihat begitu luar biasanya peningkatan akumulasi kapital yang didapatkan oleh FIFA jika ditakar dari revenue setiap tahunnya, dalam jangka waktu 4 tahun perputaran kapital yang dilakukan dalam dunia sepak bola terus menunjukkan grafik peningkatan. Sepak bola yang memang memiliki basis massa yang sangat luar biasa besar di dunia ini menjadikannya sebagai bisnis yang menawarkan potensi pasar tanpa batas. Baik dari aspek penyiaran laga-laga sepak bola di seluruh dunia, bahkan hingga kapitalisasi

${ }^{23}$ Eisenberg, Christiane. "FIFA 1975-2000: The business of a football development organisation." Historical Social Research/Historische Sozialforschung (2006): 55-68.

${ }^{24}$ FIFA Financial Report, 2017. Halaman online: https://resources.fifa.com/image/upload/fifafinancial-report2017.pdf?cloudid=pinrmrodexmnqoettgqw. Terakhir akses 19 Agustus 2018. 
Indra Kusumawardhana, Arry Bainus, Rusadi Kantaprawira| When FIFA Rules the World: Hegemoni FIFA Terhadap Indonesia Dalam Kasus Pembekuan PSSI 2015-2016

dari pemain-pemain bintang yang bertebaran di berbagai liga-liga sepak bola di dunia ini. Potensi pasar tersebut dapat kita pahami melalui ilustrasi berikut.

an estimated 250 million people are direct participants, around 1.4 billion have an interest, 1 and football's flagship tournament, the World Cup finals, attracts a cumulative global television audience of 33.4 billion.2 Only relatively recently has the game's unparalleled cross-cultural appeal been realized financially. In 1998, football's world governing body, FIFA, 3 controlled contracts worth some $£ 4$ billion; by 2001, world football's turnover was estimated at around $£ 250$ billion, equivalent to the Netherlands' GDP. ${ }^{25}$

Ilustrasi di atas dapat menjadi gambaran betapa masif dan ekstensif olah raga ini, seperti mengalir deras di dalam pusaran urat nadi peradaban manusia; bahkan jika diperbolehkan untuk menarik kesimpulan meminjam tipologi Durkheim mengenai bentuk - bentuk kultur kontemporer dapat dikatakan Sepak Bola merupakan sebuah urusan yang serius (Football is a serious life). Bahkan peningkatan pendapatan FIFA melalui bisnis sepak bola tidak terpengaruh oleh kasus "FIFA Corruption Scandal" yang menimpa FIFA di tahun 2015, hingga menyebabkan beberapa petingginya masuk penjara. $^{26}$

\footnotetext{
${ }^{25}$ Walvin, James. "The Only Game." (2001).

${ }^{26}$ Baxter, Kevin. "Soccer federation presidents arrested in widening FIFA corruption probe". 2015.

Halaman:
}

Dari sini kita dapat melihat bahwa terakumulasinya kapital melalui mendunianya sepak bola menjadikan FIFA sebuah organisasi yang mandiri dan otonom. Dalam hal ini petinggi FIFA bebas mendistribusikan kebijakan yang menurutnya sesuai dengan kepentingan FIFA terhadap negara - negara yang memiliki organisasi sepak bola yang menjadi anggota FIFA. Pendapat ini selaras dengan pendapat Giulianotti dan Robertson yang menyatakan bahwa "FIFA's executive is now capable of organizing majorities among the FAs by employing distributional policies. ${ }^{27}$

Kapasitas material FIFA semakin terlihat luar biasa dalam kasus sanksi yang menimpa sepak bola Indonesia, Akibat diberi sanksi oleh FIFA, dampak internal yang dialami Indonesia antara lain adalah FIFA menghentikan bantuan yang biasanya diberikan sebesar USD 250.000 kepada Indonesia untuk perbaikan sarana dan prasarana olahraga juga sebagai pembinaan pemain usia muda selanjutnya pemain dan wasit yang berasal dari Indonesia mengalami kerugian karena hilangnya mata pencarian mereka akibat tidak adanya kompetisi di Indonesia dan terakhir hilangnya sponsor akibat dibekukannya PSSI, perginya pemain asing untuk mengikuti kompetisi di negara lain menyebabkan daya tarik sepak bola di Indonesia semakin berkurang sehingga

http://www.chicagotribune.com/sports/soccer/lasp-sn-concacaf-conmebol-presidents-arrested-infifa-probe-20151203-story.html. Terakhir akses 19 Agustus 2018.

27 Giulianotti, Richard and Roland Robertson. 2012. 'Mapping the Global Football Field: A sociological Model of Transnational Forces within the World Game.' British Journal of Sociology 63(2), 216-240. 
Indra Kusumawardhana, Arry Bainus, Rusadi Kantaprawira| When FIFA Rules the World: Hegemoni FIFA Terhadap Indonesia Dalam Kasus Pembekuan PSSI 2015-2016

sponsor kurang tertarik berinvestasi di Indonesia. $^{28}$

Normalisasi organisasi sepak bola Indonesia baru terjadi setelah FIFA mencabut sanksi pembekuan PSSI. Federasi Sepak Bola Asia (AFC) sebagai organisasi regional di bawah FIFA menggelontorkan dana segar kepada PSSI sejumlah USD. 600.000 atau sebesar Rp. 7.8 Miliar. $^{29}$ Bahkan dokumen financial report FIFA, mengungkap bahwasanya berdasarkan statuta FIFA no.12 pasal 1 butir (e) yang memberikan hak kepada organisasi sepak nasional yang menjadi anggota FIFA untuk to take part in FIFA's assistance and development programme. Indonesia berhak untuk mendapatkan bantuan FIFA dalam kerangka program "Development \& Education" sebesar USD 2,9 juta pada tahun $2017 .{ }^{30}$

Ilustrasi di atas dapat menjadi gambaran kapasitas material FIFA baik pada tataran makro, maupun ketika berkaitan dengan negara-negara yang memiliki organisasi sepak bola di bawah kekuasaan FIFA selaku institusi global di dalam sepak bola. Namun, analisis artikel ini berpendapat, jumlah yang digelontorkan FIFA bukanlah jumlah yang fantastis. Apalagi jika

28 Saceira, Tibortius. “"Diplomasi Indonesia Dalam Mengakhiri Sanksi FIFA Tahun 2015". eJournal Ilmu Hubungan Internasional, 2018, 6 (1) 095-108

${ }^{29}$ Setyawatie, Wina. "PSSI Dapat Bantuan Rp 7,8 Miliar dari AFC". 2017. Diakses pada halaman http://www.pikiran-rakyat.com/olahraga/2017/02/07/pssi-dapat-bantuan-rp-78-miliardari-afc-392831. Terakhir akses 19 Agustus 2018

${ }^{30}$ FIFA Financial Report, 2017. Halaman online: https://resources.fifa.com/image/upload/fifafinancial-report-

2017.pdf?cloudid=pinrmrodexmnqoettgqw. Terakhir akses 19 Agustus 2018. dibandingkan dengan anggaran negara yang seharusnya mampu secara mandiri mendanai olah raga sepak bola pada aras nasional. Oleh karenanya, aspek kedua, yakni kapasitas material dalam konteks keberadaan FIFA tidak bisa berdiri sendiri. Selain ditopang oleh tata kelola insititutional dari FIFA, kapasitas material FIFA juga ditopang oleh dimensi ide dari olahraga sepakbola. Oleh karenanya, pembahasan selanjutnya akan mencoba menelusuri dimensi ide yang menopang FIFA sebagai institusi global pada dunia sepak bola.

\section{Kekuatan Ide di Dalam Olah Raga Sepak Bola}

Menurut Cox, ide sebagai kekuatan yang menopang hegemoni memiliki dua varian; pertama, ide yang berperan sebagai intersubjective meaning. Kedua, ide yang memainkan shared notions of the nature of social relations yang awamnya menjadi jangkar terkait prilaku dan kebiasaan yang diterima oleh masyarakat. ${ }^{31}$ Ide pada varian makna intersubjektif, menurut pemahaman artikel ini memberikan basis terkait hubungan antara kelas dominan dengan massa yang lebih luas. Dimana kekuasaan untuk mengatur ditopang oleh aspek konsensual yang diartikulasikan di benak kelas-kelas yang secara struktur di bawah kendali hegemon. Kemudian ide pada varian kedua, berlandaskan pada ide intersubjektif yang bermain di dalam benak para aktor, kelas dominan memunculkan berbagai norma dan aturan yang menjadikan

31 Cox, Robert W. "Social forces, states and world orders: beyond international relations theory." Millennium 10, no. 2 (1981): 126-155 
Indra Kusumawardhana, Arry Bainus, Rusadi Kantaprawira| When FIFA Rules the World: Hegemoni FIFA Terhadap Indonesia Dalam Kasus Pembekuan PSSI 2015-2016

hubungan antar aktor di dalam struktur memiliki kebiasaan dan prilaku yang dianggap layak di dalam hubungan sosial tertentu.

Secara intersubjektif, sepak bola merupakan olahraga yang telah menyatukan dunia secara luas. Sejak permainan sepakbola dipopulerkan oleh Inggris Raya pada tahun 1863, kemudian FIFA berdiri pada tahun 1904 di Paris. ${ }^{32}$ Sepak bola telah menjadi olahraga yang sangat terkenal; basis penggemar sepakbola di 5 negara Eropa (Spanyol, Italia, Jerman, Inggris Raya, dan Prancis) berjumlah 131 juta jiwa, sedangkan di Rusia $52 \%$ populasinya menggemari Sepakbola sebagai olahraga rakyat. ${ }^{33}$ Bahkan jika berbicara basis penggemar perempuan terhadap olahraga ini, data yang sama dari Nielsen menunjukkan bahwasanya $70 \%$ perempuan yang dijadikan responden menyatakan pria yang bermain di Piala Dunia sangat menarik (Very Appealing).

Sedangkan di Indonesia, basis massa penggila sepakbola mencapai $77 \%$, terutama ketika Timnas Indonesia mendapatkan kesempatan untuk berlaga di ajang kompetisi sepakbola internasional. Angka ini menjadikan Indonesia sebagai negara dengan prosentase penggila sepakbola kedua

32 FIFA.com. "History of FIFA-Foundation". Halaman online: https://www.fifa.com/aboutfifa/who-we-are/history/index.html terakhir diakses pada 21 Agustus 2018.

33 Nielsen.com. "Fan Favorite: The Global Popularity Of Football Is Rising". Halaman online:

http://www.nielsen.com/id/en/insights/news/2018 /fan-favorite-the-global-popularity-of-football-isrising.html terakhir diakses pada 21 Agustus 2018 tertinggi setelah Nigeria. ${ }^{34}$ Berlandaskan data ini, jika populasi Indonesia ada pada kisaran 250 jiwa, maka penggemar sepakbola di Indonesia mencapai 175 juta jiwa. Bahkan melebihi jumlah penggila sepakbola di lima negara besar Eropa Barat yang memiliki Liga Sepak Bola terkenal.

Berlandaskan fakta-fakta empiris tersebut, dapat dikatakan masyarakat dunia memiliki keterikatan yang sangat kuat terhadap olahraga sepakbola. Menurut Matthew Nicholson dan Russell Hoye di dalam bukunya "Sport and Social Capital" menyatakan bahwasanya "...in other words, there is an inherent logic in the idea that the more connections individuals make within their communities the better off they will be emotionally, socially, physically and economically". Semakin besar dan fanatik massa yang menggemari sepakbola, maka olahraga ini menjadi aktifitas yang lebih dari sekedar olahraga untuk menjaga kebugaran, namun terbenam secara mendalam di benak semua individu yang mencintai sepakbola sebagai olahraga rakyat. Pada titik ini, meminjam terminologi Bourdieu, dapat dikatakan sepakbola memiliki kapital sosial yang sangat luar biasa. ${ }^{35}$

\footnotetext{
${ }^{34}$ Arifianto, Nova. "Indonesia Negara Penggila Sepak Bola Nomor Dua di Dunia". 2017. Halaman online: https://www.cnnindonesia.com/olahraga/2017121 9204103-142-263606/indonesia-negara-penggilasepak-bola-nomor-dua-di-dunia terakhir akses pada 21 Agustus 2018.

${ }^{35}$ Bourdieu pada tahun 1986 menjelaskan Kapital Sosial sebagai "social capital was "the aggregate of the actual or potential resources which are linked to possession of a durable network of more or less institutionalised relationships of mutual acquaintance or recognition." Lihat. Bourdieu,
} 
Indra Kusumawardhana, Arry Bainus, Rusadi Kantaprawira| When FIFA Rules the World: Hegemoni FIFA Terhadap Indonesia Dalam Kasus Pembekuan PSSI 2015-2016

Modalitas sosial ini direkatkan oleh ide besar dari sepakbola yang memuat nuansa adicita humanis, dimana sepakbola menyatukan semua individu di dunia ini, tidak hanya merekatkan relasi sosial namun juga memberikan kesempatan kepada siapa pun di muka bumi ini untuk berkompetisi dan menjadi pemain sepakbola terkenal. Seperti yang diungkap oleh Louis Saha; pemain kulit hitam berkebangsaan Prancis ini menyatakan "Football brings everyone together, it brings smiles to people's faces, it brings races together and more". Lebih jauh lagi, Saha menyatakan, "Football is a symbol that means that everyone can- at the same time, compete and live together". Menjadikan sepakbola sebagai simbolisasi dari kesetaraan antar bangsa di dunia ini merupakan penjabaran yang sangat dalam dan bernuansa filsafat pergerakkan. Sehingga, tulisan ini dapat memahami betapa dalamnya ungkapan tersebut untuk seorang manusia yang warna kulitnya sering dikaitkan dengan fenomena perbudakan yang kerap terjadi di dalam rentang sejarah dunia.

Pada titik ini, ketika membenturkan makna masyarakat di dalam sepakbola dengan masyarakat di dalam negara dan kedaulatannya. Praktik kenegaraan modern sampai saat ini masih merupakan aktus yang melandaskan dirinya pada sebuah gagasan sentral yakni "Kedaulatan. Berdasarkan Traktat Westphalia 1648, setidaknya ada 3 (Tiga) indikator yang menandakan sebuah negara memiliki "Kedaulatan": Pertama, memiliki batas atau teritori yang jelas; Kedua, Kedaulatan Kedalam, yakni memiliki pemerintahan yang bertugas mengatur

Pierre. "The forms of capital. (1986)." Cultural theory: An anthology 1 (2011): 81-93. kehidupan domestik; Ketiga, kedaulatan keluar, dimana tidak ada kekuatan lain yang lebih tinggi dari negara. ${ }^{36}$

Dari sini, dapat kita lihat kontradiksi ide yang termuat di dalam masyarakat sepakbola sebagai olahraga, ketika dikomparasikan dengan pemahaman terkait masyarakat negara di dalam sistem internasional. Jika masyarakat sepakbola merepresentasikan simbol inklusivitas masyarakat dunia yang transenden, negara merupakan representasi dari eksklusifitas masyarakat secara imanen di dalam sistem internasional yang selalu digaungkan anarki. Distingsi yang nampak dalam pemahaman ini menjadikan kedaulatan negara memiliki keterbatasan dalam mengatur bahkan mencegah preferensi masyarakat terhadap sepakbola yang memiliki basis loyalitas massa yang lebih transenden dan cair.

Oleh karenanya, dalam konteks tata kelola sepakbola dunia, kemanjuran doktrin ala westphalia dengan kedaulatannya menjadi berkurang ketika pemerintahan oleh aktor non-negara dapat menyediakan kebutuhan yang dituntut oleh publik dimana negara sendiri tidak memiliki kapasitas dalam menyediakan kebaikan yang serupa. Seperti yang diungkap oleh Calvert, assumed that persistent international private governance regimes represent an 36 Stephen D Krasner memberikan sebuah elaborasi yang lebih spesifik mengenai Kedaulatan dalam tulisannya "Sovereignty and its discontent" Setidaknya ada Empat (4) indikator yang menandakan sebuah negara memiliki "Kedaulatan" : Pertama, memiliki batas atau teritori yang jelas; Kedua, Kedaulatan kedalam (Domestic Sovereignty); Ketiga, kedaulatan keluar (Westphalian Sovereignty) Keempat: Kedaulatan Internasional (International Legal Sovereignty). (Stephen D Krasner, 1999) 
Indra Kusumawardhana, Arry Bainus, Rusadi Kantaprawira| When FIFA Rules the World: Hegemoni FIFA Terhadap Indonesia Dalam Kasus Pembekuan PSSI 2015-2016

institutional equilibrium whose stability results from the absence of pareto-improving alternatives (Calvert 1995a, b). Selaras dengan pendapat tersebut, Dixit juga menyatakan bahwasanya "Moreover, in any moderately complex social context, institutional change requires considerable efforts". 37

Berangkat dari titik ini, FIFA selaku institusi sepakbola global memiliki keistimewaan dalam memunculkan norma yang harus dipatuhi oleh seluruh negara yang menginginkan rakyatnya memiliki Tim Nasional yang dapat berlaga pada tataran yang lebih tinggi dari kompetisi domestik, yakni kompetisi internasional. Karena baik pada aspek tata kelola institusional maupun kapasitas material dan ide-ide yang melandasi sepakbola, FIFA memiliki kapasitas jauh melebihi kapasitas negara untuk mengontrol aktifitas sepakbola dunia. Sehingga setiap negara yang ingin berlaga pada perhelatan internasional harus mengikuti norma yang dibentuk oleh FIFA dalam menjaga hakikat sepakbola sebagai olahraga rakyat.

Norma utama yang dimunculkan oleh FIFA dalam menjaga independensi Sepakbola adalah "Non-Intervention Principle" dari pihak ketiga terutama negara dalam mengatur aktifitas sepakbola pada tataran manapun, bahkan pada aras domestic sepakbola harus bebas dari campur tangan negara. Norma ini semakin menguat pada awal tahun 1990-an setelah FIFA menerapkan kebijakan pembekuan ataupun mengancam untuk membekukkan federasi

37 Dixit, Avinash. 'Governance Institutions and Economic Activity.' 2009. American Economic Review 99(1), 19. sepakbola nasional yang dianggap terlalu banyak diintervensi oleh kuasa negara. ${ }^{38}$ Selain kehilangan hak untuk mengikuti kesempatan untuk terlibat dalam berbagai perhelatan sepakbola internasional. Konsekuensi dari pembekuan ini, federasi yang dibekukan kehilangan kesempatan untuk mendapat bantuan secara finansial dari FIFA untuk pengembangan institusi setiap tahunnya.

Selama tiga dekade, FIFA telah berhasil mengembangkan sepakbola sebagai cabang olahraga yang sangat terkenal di seluruh dunia. Menanjaknya popularitas sepakbola berkelindan dengan pendapatan FIFA yang terus meroket setiap tahunnya melalui siaran pertandingan dan berbagai kontrak lisensi. ${ }^{39}$ Menurut FIFA, lebih dari $70 \%$ pendapatannya diredistribusikan kembali kepada federasi-federasi sepakbola pada aras nasional melalui berbagai program bantuan dan pengembangan. ${ }^{40}$ Dana-dana tersebut, untuk beberapa federasi kecil di dunia merupakan bantuan yang sangat bermakna, bahkan merepresentasikan porsi

38 Sebagai contoh dari tindakan ini, lihat surat dari Fatma Samoura, Sekretaris Jenderal, FIFA, kepada seluruh anggota FIFA pada 17 Maret 2017, surat tersebut diakses secara online pada halaman

http://resources.fifa.com/mm/document/affederati on/administration/02/87/68/52/circularno.1577suspensionofthemalianfootballfederationasof $17 \mathrm{~m}$ arch2017anduntilfurthernotice neutral.pdf.

Terakhir akses pada 21 Agustus 2018.

39 FIFA, FINANCIAL AND GOVERNANCE

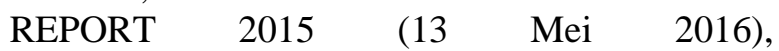
http://resources.fifa.com/mm/document/affederati on/administration/02/77/08/71/gb15_fifa_web_en _neutral.pdf at 16. Terakhir akses 21 Agustus 2018.

40 FIFA Expenditure, FIFA.COM, http://www.fifa.com/governance/finances/expend iture.html. Terakhir akses 21 Agustus 2018. 
Indra Kusumawardhana, Arry Bainus, Rusadi Kantaprawira| When FIFA Rules the World: Hegemoni FIFA Terhadap Indonesia Dalam Kasus Pembekuan PSSI 2015-2016

yang cukup besar dari anggaran tahunan mereka. ${ }^{41}$ Bertolak dari penjelasan tersebut, sanksi pembekuan dari FIFA memiliki konsekuensi konkret yang dapat mematikan federasi sepakbola nasional secara institusional. Dalam hal ini FIFA sebagai pemerintahan dari aktor non-negara yang bersifat global mempunyai kekuatan dikarenakan tidak ada organisasi internasional lainnya yang dapat mengatur sepak bola dan menyediakan solusi yang dapat dilakukan dalam meningkatkan kualitas sepak bola setiap negara anggota.

Selaras dengan pemahaman Cox terkait hegemoni pada tataran internasional yang menyatakan "Historical phases are thereby identified when a coherent fit has occurred between material power, the development of collective world images and the administration of an order through a set of institutions claiming universality. ${ }^{42}$ Secara sepihak FIFA dapat memaksa untuk setiap organisasi sepak bola dalam tataran nasional dapat diakui kesahihannya dalam konteks dunia internasional jika telah mengikuti seluruh aturan main yang ditetapkan FIFA. Bagaimana jika tidak ikut dikarenakan intervensi politik oleh negara? Maka negara

41 Governance: Finances, FIFA.COM, http://www.fifa.com/governance/finances/.

Terakhir akses 21 Agustus 2018. Untuk pembahasan terkait bagaimana FIFA mengelola pendapatannya, lihat Isabelle Frazier, FIFA's Finances - Where Does All the Money Come From?, THE TELEGRAPH (29 Mei, 2015), http://www.telegraph.co.uk/sport/football/fifa/11 635985/Fifas-finances-where-does-all-themoneycome-from.html. Terakhir akses 21 Agustus 2018.

${ }^{42}$ Cox, Robert W. "Social forces, states and world orders: beyond international relations theory." Millennium 10, no. 2 (1981): 126-155. yang bersangkutan akan langsung berhadapan dengan rakyatnya yang mencintai sepak bola sebagai identitas global. Hal inilah yang nampak pada kasus yang menimpa Indonesia. Sport is prone to politicization because it can serve as symbol of cohesion and exclusion due to its dramatic and antagonist qualities. ${ }^{43}$

Sejenak kita perlu melihat kembali pemahaman yang ada dalam melihat fenomena yang terjadi dalam kisruh antara KEMENPORA-PSSI dan FIFA. Sekilas ini hanyalah masalah sepak bola yang mungkin menurut pandangan masyarakat jauh dari urusan perebutan kekuasaan ala realis atau mengenai kekuatan pasar dan kebebasan individu ala kapitalis-liberalis apalagi tidak juga dikaitkan dengan struktur yang tercipta dari sudut pandang strukturalis marxis. Namun, keberanian KEMENPORA dibawah kepemimpinan Imam Nahrowi dalam melakukan pembekuan terhadap PSSI bisa dibilang sebagai langkah yang sangat diluar ekspektasi publik. Selama ini masyarakat sepak bola Indonesia selalu dihantui dengan sanksi FIFA yang mengacu pada Statuta FIFA Pasal 13 Ayat 1 (j): "to comply fully with all other duties arising from these statutes and other regulations.". Pasal itu menjadi senjata untuk memukul mundur keinginan pemerintah negara untuk turut campur dalam sepak bola, persepsi ini bukan hanya terjadi di Indonesia. Ancaman tersebut secara otomatis menjadikan kebijakan mengintervensi PSSI sebagai kebijakan yang tidak populer. Bahkan negara seperti Yunani,

${ }^{43}$ Giulianotti, R., \& Robertson, R. (2004). The globalization of football: a study in the glocalization of the 'serious life'. The British journal of sociology, 55(4), 545-568. 
Indra Kusumawardhana, Arry Bainus, Rusadi Kantaprawira| When FIFA Rules the World: Hegemoni FIFA Terhadap Indonesia Dalam Kasus Pembekuan PSSI 2015-2016

Polandia dan Spanyol pernah merasakan kekarnya statuta FIFA yang dapat menjadi senjata untuk melemahkan otoritas negara dalam hal sepak bola. ${ }^{44}$

Indonesia yang mencoba untuk melakukan langkah berani dengan membekukan PSSI sebagai organisasi yang secara sahih diakui oleh FIFA untuk mengatur sepak bola di Indonesia mengalami nasib serupa dengan dengan tiga negara tersebut. Imam Nahrowi selaku Menteri Pemuda dan Olah Raga (MENPORA) mendapatkan hujatan publik yang berpendapat bahwa kebijakan tersebut dilandaskan pada minimnya kompetensi dalam memahami mekanisme sepak bola secara holistik. $^{45}$

Perkembangan yang selanjutnya menjadi menarik ketika kebijakan yang dilakukan untuk mengatur pranata domestik nasional ternyata ketika FIFA masuk dan membuat kebijakan sebagai otoritas sepak bola internasional berimplikasi terhadap kebijakan KEMENPORA untuk membekukan PSSI menjadi sebuah kebijakan yang melambung hingga dimensi foreign policy. Akhirnya untuk menghadapi tuntutan untuk bernegosiasi pada tataran internasional KEMENPORA membentuk tim kecil yang berisikan pakar diplomasi Indonesia sebagai juru bicara Kementerian Pemuda dan Olahraga yakni Gatot S. Dewabroto, bekas

\footnotetext{
${ }^{44}$ Borja Garcia membahas 3 kasus ini secara komperehensif dalam jurnal "keeping private governance private: Is FIFA blackmailing national governments?"

45 Sumber media online http://soccer.sindonews.com/read/1016991/58/me npora-diminta-belajar-lagi-soal-mekanisme-

kompetisi-dan-statuta-1435243521, diakses pada tanggal 06 Januari 2016 pada pukul 20.00 WIB
}

Duta Besar Indonesia untuk Swiss Djoko Susilo, bekas Duta Besar Indonesia untuk Perserikatan Bangsa-bangsa Makarim Wibisono, bekas Ketua Komite Olimpiade Indonesia Rita Subowo, serta Dede Sulaiman, mantan pemain nasional. ${ }^{46}$

Indonesia sebagai sebuah negara berdaulat dipaksa untuk berdiplomasi keluar negeri untuk kebijakan yang ditujukan untuk organisasi yang berada di dalam kedaulatannya. Bahkan langkah - langkah diplomasi tersebut terkesan tidak mendapatkan hasil maksimal karena dibatasi oleh mekanisme FIFA sebagai organisasi internasional dalam melakukan dialog dengan negara yang berdaulat. Lantas lebih ironis lagi ketika melihat bahwa diplomasi ini ditujukan pada organisasi internasional yang secara entitas bersifat non-state actor.

Sehingga dapat kita lihat proses bagaimana kekuatan FIFA ini menjadi sebuah kerangka yang sangat kekar untuk negara manapun di dunia ini. Beberapa negara yang tidak patuh dengan peraturan FIFA harus siap untuk mendapatkan sanksi keras dan berhadapan langsung dengan kemarahan publik dalam negeri atas ketidak patuhannya terhadap aturan main FIFA. Indonesia menjadi contoh empiris yang membuktikan hukum besi FIFA terhadap negara-bangsa. Di dalam representasi FIFA sebagai institusi global ini, pandangan Cox terkait "A hegemonic world order therefore emerges out of the successful formation of an international historic bloc of social forces which in turn is premised upon the

46 Tempo.co, 2015. Sumber online: http://bola.tempo.co/read/news/2015/12/07/2377 25544/komite-ad-hoc-pssi-pemerintah-kalahselangkah. Terakhir akses 31 Agustus 2018 
Indra Kusumawardhana, Arry Bainus, Rusadi Kantaprawira| When FIFA Rules the World: Hegemoni FIFA Terhadap Indonesia Dalam Kasus Pembekuan PSSI 2015-2016

articulation of a dominant ideology accepted by subordinate classes ",47, telah menemukan konsteks empirisnya.

Hegemoni FIFA ditopang oleh tata kelola institusional yang telah begitu mapan, kapasitas material yang mampu mempenetrasi setiap negara di dunia ini, serta modalitas ide sebagai sosial kapital yang menjadikan masyarakat dunia memiliki keterkaitan kuat dengan sepakbola sebagai olahraga. Kesadaran transendental tersebut dapat dipahami melalui narasi intelektual Cox yang menjabarkan bahwasanya "[H] egemony at the international level is ... not merely an order among states. It is an order within a world economy with a dominant mode of production which penetrates into all countries and links into other subordinate modes of production. It is also a complex of international social relationships which connects the social classes of the different countries". ${ }^{48}$ Pada titik ini, tulisan ini dapat memahami ketidakberdayaan negara ketika berhadapan dengan Global Sport Governance seperti FIFA.

\section{Kesimpulan}

Tidak dapat dipungkiri, berdasarkan apa yang telah dinarasikan dalam tulisan ini bahwa FIFA telah secara luar biasa dapat mempertahankan otonomi dari otoritasnya dalam hal sepak bola. Lebih dari sekedar mempertahankan legitimasinya sebagai

\footnotetext{
${ }^{47}$ Burnham, Peter. "Neo-Gramscian hegemony and the international order." Capital \& Class 15, no. 3 (1991): 73-92.

48 Cox, Robert W., and Timothy J. Sinclair. Approaches to world order. No. 40. Cambridge University Press, 1996. Hal. 137
}

sebuah aktor non-negara yang mempunyai pemerintahan imajiner, namun juga dapat memaksa pemerintahan yang berdaulat untuk tersungkur dalam menapaki jalan perubahan nasional melalui kebijakan olah raga yang nampak dari kisruh KEMENPORA versus PSSI dan FIFA. Artikel ini telah menunjukkan ketidakberdayaan Indonesia dalam menghadapi FIFA dikarenakan hegemoni FIFA di dalam sistem internasional yang ditopang oleh tata kelola institusi yang begitu mapan, kapasitas material yang mampu mempenetrasi seluruh negara-negara di dunia ini, serta modalitas ide dari sepakbola sebagai olahraga yang merepresentasikan inklusivitas masyarakat dunia serta norma non-intervensi yang ditegakkan untuk menjaga kesucian sepakbola dari kuasa negara. 
Indra Kusumawardhana, Arry Bainus, Rusadi Kantaprawira| When FIFA Rules the World: Hegemoni FIFA Terhadap Indonesia Dalam Kasus Pembekuan PSSI 2015-2016

\section{DAFTAR PUSTAKA}

Arifianto, Nova. "Indonesia Negara Penggila Sepak Bola Nomor Dua di Dunia". 2017. Halaman online: https://www.cnnindonesia.com/olahraga/20171219204103-142263606/indonesia-negara-penggila-sepak-bola-nomor-dua-di-dunia terakhir akses pada 21 Agustus 2018.

Ariyanto, Khrisna. "Analyzing the Conflict between Football Organizations in Indonesia." Procedia-Social and Behavioral Sciences 115 (2014): 430-435.

Baselgovernance.org. Sumber Online: https://www.baselgovernance.org/sites/collective.localhost/files/documents/igc/first_r eport_by_igc_to_fifa_exco.pdf. Terakhir akses 20 Agustus 2018.

Baxter, Kevin. "Soccer federation presidents arrested in widening FIFA corruption probe". 2015. Halaman: http://www.chicagotribune.com/sports/soccer/la-sp-sn-concacafconmebol-presidents-arrested-in-fifa-probe-20151203-story.html. Terakhir akses 19 Agustus 2018.

Börzel, Tanja and Risse, Thomas (2010). 'Governance without a state: Can it work?' Regulation and Governance 4(1), 113-134.

Bourdieu, Pierre. "The forms of capital. (1986)." Cultural theory: An anthology 1 (2011): 8193

Burnham, Peter. "Neo-Gramscian hegemony and the international order." Capital \& Class 15, no. 3 (1991): 73-92.

Cashore, Benjamin. 2003. Legitimacy and the Privatization of Environmental Governance: How Non- State Market-Driven (NSMD) Governance Systems Gain Rule-Making Authority. Governance 15(4), 503-529.

Chappelet, Jean Loup. Autonomy of Sport in Europe. 2010. Strasbourg: Council of Europe Publishing.

Chaudary, Ganga Dhar. Politics, Ethics, and Social Responsibility of Business. 2005. Paragon books.

Coe, Neil M., Peter Dicken, and Martin Hess. "Global production networks: realizing the potential." Journal of economic geography 8.3 (2008): 271-295.

Cox, Robert W. "Social forces, states and world orders: beyond international relations theory." Millennium 10, no. 2 (1981): 126-155.

Cox, Robert W., and Timothy J. Sinclair. Approaches to world order. No. 40. Cambridge University Press, 1996. 139

Cutler, A. Claire, Virginia Haufler, and Tony Porter, eds. Private authority and international affairs. Suny Press, 1999.

Dicken, Peter. Global shift: Reshaping the global economic map in the 21st century. Sage, 2003.

Dingwerth, Klaus and Philipp Pattberg. 2006. 'Global Governance as Perspective on World Politics.'Global Governance 12(2), 185-203. 
Indra Kusumawardhana, Arry Bainus, Rusadi Kantaprawira| When FIFA Rules the World: Hegemoni FIFA Terhadap Indonesia Dalam Kasus Pembekuan PSSI 2015-2016

Dingwerth, Klaus. 2008. 'Private Transnational Governance and the developing World: A Comparative Perspective.' International Studies Quarterly 52(3), 607-634.

Dixit, Avinash. 2009. 'Governance Institutions and Economic Activity.' American Economic Review 99(1), 5-24

Eick, Volker. "A neoliberal sports event? FIFA from the Estadio Nacional to the fan mile." City 14, no. 3 (2010): 278-297.

Eisenberg, Christian. 2006b. 'FIFA 1975-2000: The Business of a Football Development Organization.' Historical Social Research 31(1), 55-68

FIFA.com. "History of FIFA-Foundation". Halaman online: https://www.fifa.com/aboutfifa/who-we-are/history/index.html terakhir diakses pada 21 Agustus 2018.

FIFA, FINANCIAL AND GOVERNANCE REPORT 2015 (13 Mei 2016), $\mathrm{http} / / /$ resources.fifa.com/mm/document/affederation/administration/02/77/08/71/gb15 _fifa_web_en_neutral.pdf at 16. Terakhir akses 21 Agustus 2018.

FIFA Financial Report, 2017. Halaman online: https://resources.fifa.com/image/upload/fifafinancial-report-2017.pdf?cloudid=pinrmrodexmnqoettgqw.. Terakhir akses 19 Agustus 2018.

FIFA Expenditure, FIFA.COM, http://www.fifa.com/governance/finances/expenditure.html. Terakhir akses 21 Agustus 2018.

Foster, Ken. "Is there a global sports law." Ent. L. 2 (2003): 2

Fuchs, Doris A. 2002. 'Globalization and Global Governance: Discourses on Political Order at the Turn of the Century.' In Transformative Change and Global Order: Reflections on Theory and Practice, ed. Doris Fuchs and Friedrich Kratochwil, Münster: LIT, 1-23.

García, Borja, and Henk Erik Meier. "Limits of interest empowerment in the European Union: The case of football." Journal of European integration 34.4 (2012): 359-378.

García, Borja, and Henk-Erik Meier. "Keeping private governance private: is FIFA blackmailing national governments?." (2013).

Gereffi, Gary. "The global economy: organization, governance, and development." The handbook of economic sociology 2 (2005): 160-182.

Gereffi, Gary, John Humphrey, and Timothy Sturgeon. "The governance of global value chains." Review of international political economy 12.1 (2005): 78-104.

Giddens, Anthony. The nation-state and violence. Vol. 2. Univ of California Press, 1985.

Giulianotti, Richard, and Roland Robertson. "The globalization of football: a study in the glocalization of the 'serious life'." The British Journal of Sociology 55.4 (2004): 545568.

Giulianotti, Richard and Roland Robertson. 2012. 'Mapping the Global Football Field: A sociological Model of Transnational Forces within the World Game.' British Journal of Sociology 63(2), 216-240.

Giulianotti, Richard, ed. Sport and modern social theorists. Hampshire: Palgrave Macmillan, 2004. 
Indra Kusumawardhana, Arry Bainus, Rusadi Kantaprawira| When FIFA Rules the World: Hegemoni FIFA Terhadap Indonesia Dalam Kasus Pembekuan PSSI 2015-2016

Governance: Finances, FIFA.COM, http://www.fifa.com/governance/finances/. Terakhir akses 21 Agustus 2018.

Gramsci, Antonio. Selections from the Prison Notebooks of Antonio Gramsci: Ed. and Transl. by Quintin Hoare and Geoffrey Nowell Smith. Eds. Geoffrey Nowell-Smith, and Quintin Hoare. International Publishers, 1971. (55-60, 415-25)

Hadiwinata, B. S., 2002. Politik Bisnis Internasional. Kanisius. Hal. 47

Held, David, and Anthony G. McGrew, eds. Governing globalization: power, authority and global governance. Cambridge: Polity, 2002.

Held, David, et al. Global transformations, introduction. Cambridge: Polity Press, 1999.

Henderson, Jeffrey, et al. "Global production networks and the analysis of economic development." Review of international political economy 9.3 (2002): 436-464.

Hinsley, Francis H. "The concept of sovereignty and the relations between states." Journal of International Affairs 21.2 (1967): 242-252.

Isabelle Frazier, FIFA's Finances - Where Does All the Money Come From?, THE TELEGRAPH (29 Mei, 2015), http://www.telegraph.co.uk/sport/football/fifa/11635985/Fifas-finances-where-doesall-themoney-come-from.html. Terakhir akses 21 Agustus 2018.

Jacobinmag.com. "Sepp Blatter World Cup Qatar Charges". Sumber online: https://www.jacobinmag.com/2015/06/sepp-blatter-world-cup-qatar-charges/. Diakses pada 05 Januari 2016 pukul 11.00

Keohane, Robert O. "International institutions and state power: Essays in international relations theory." (1989).

Keohane, Robert Owen, and Joseph S. Nye. Power and interdependence: World politics in transition. 2nd ed. Boston: Little, Brown, 1977.

Koenig-Archibugi, Mathias. 2004. 'Transnational Corporations and Public Accountability.' Government and Opposition 39(2), 234-259.

Krasner, Stephen D. Sovereignty: organized hypocrisy. Princeton University Press, 1999.

Kusumawardhana, Indra dan Muhammad Baddarudin. "FIFA and Sport Sovereignty: Analyzing the Triangular Relationship among the FIFA, Kemenpora RI, and the PSSI." Proceeding Re-examining Governance: Strengthening Citizenship in The Changing World (2016): 237

Meier, Henk Erik. 2008. 'Institutional Complementarities and Institutional Dynamics: Exploring Varieties in European Football Capitalism.' Socio-Economic Review 6(4), 99-133.

Neale, Walter C. "The peculiar economics of professional sports: A contribution to the theory of the firm in sporting competition and in market competition." The Quarterly Journal of Economics (1964): 1-14.

Nielsen.com. "Fan Favorite: The Global Popularity Of Football Is Rising”. Halaman online: http://www.nielsen.com/id/en/insights/news/2018/fan-favorite-the-global-popularityof-football-is-rising.html terakhir diakses pada 21 Agustus 2018 
Indra Kusumawardhana, Arry Bainus, Rusadi Kantaprawira| When FIFA Rules the World: Hegemoni FIFA Terhadap Indonesia Dalam Kasus Pembekuan PSSI 2015-2016

Peters, B. Guy and Jon Pierre. 1998. 'Governance without Government? Rethinking Public Administration.' Journal of Public Administration, Research and Theory 8(2), 223243.

Pssi.or.id. "Sejarah PSSI". Diakses secara online pada halaman http://www.pssi.or.id/dev/page/detail/5/Sejarah-PSSI. Terakhir akses pada 19 Agustus 2018.

Republika.co.id.

http://www.republika.co.id/berita/sepakbola/ligaindonesia/15/06/29/nqpo76k-kemenpora-pssi-dibekukan-karena-tak-patuh , Diakses pada tanggal 20 Desember 2015 pukul 22.00 WIB

Ronit, Karsten. "Institutions of Private Authority in Global Governance Linking Territorial Forms of Self-Regulation." Administration \& Society 33.5 (2001): 555-578.

Rosenau, James N. "Governance in a new global order." Governing globalization: Power, authority and global governance (2002): 70-86.

Rosenau, James N. Turbulence in world politics: A theory of change and continuity. Princeton University Press, 1990.

Rosenau, James, and Ernst-Otto Czempiel. 1992. Governance without Government: Order and Change in World Politics. Cambridge: Cambridge University Press.

Saceira, Tibortius. ““Diplomasi Indonesia Dalam Mengakhiri Sanksi FIFA Tahun 2015”. eJournal Ilmu Hubungan Internasional, 2018, 6 (1) 095-108

Scully, Gerald W. The market structure of sports. University of Chicago Press, 1995.

Septi, Amalia. 2015. "Gelar Demonstrasi, Jakmania Minta Menpora Cabut SK Pembekuan PSSI". Diakses secara daring pada halaman https://sport.detik.com/sepakbola/ligaindonesia/2988856/gelar-demonstrasi-jakmania-minta-menpora-cabut-skpembekuan-pssi. pada tanggal 19 Agustus 2018 pukul 00.00 WIB

Setyawatie, Wina. "PSSI Dapat Bantuan Rp 7,8 Miliar dari AFC". 2017. Diakses pada halaman http://www.pikiran-rakyat.com/olah-raga/2017/02/07/pssi-dapat-bantuan-rp78-miliar-dari-afc-392831. Terakhir akses 19 Agustus 2018

Soccer.sindonews.com. "Menpora Diminta Belajar Lagi Soal Mekanisme Kompetisi dan Statuta. Sumber online: http://soccer.sindonews.com/read/1016991/58/menporadiminta-belajar-lagi-soal-mekanisme-kompetisi-dan-statuta-1435243521. Terakhir akses 21 Agustus 2018.

Sugden, John. 2002. 'Network football.' In Power Games: A Critical Sociology of Sport, ed. John Sugden and Alan Tomlinson. London, New York: Routledge, 61-80.

Sugden, John, and Alan Tomlinson. "Global power struggles in world football: FIFA and UEFA, 1954-74, and their legacy." The International Journal of the History of Sport 14.2 (1997): 1-25.

Sugden, John and Alan Tomlinson. 1998b. FIFA and the Contest for World Football: Who rules the People's Game? Cambridge: Polity

Sugden, John and Alan Tomlinson. 2000. 'Football, Ressentiment and Resistance in the Break-up of the former Soviet Union.' Culture, Sport, Society 3(2), 89-108. 
Indra Kusumawardhana, Arry Bainus, Rusadi Kantaprawira| When FIFA Rules the World: Hegemoni FIFA Terhadap Indonesia Dalam Kasus Pembekuan PSSI 2015-2016

Sugiono, Muhadi. "Kritik Antonio Gramsci terhadap pembangunan dunia ketiga". Pustaka Pelajar. 1999. Hal.35

Tomlinson, Alan. 2000. 'FIFA and the Men who made it.' Soccer and Society 1(1), 55-71.

Tomlinson, Alan. 2007. 'Lord, don't stop the Carnival: Trinidad and Tobago at the 2006 FIFA World Cup.' Journal of Sport and Social Issues 31(3), 259-282

Walvin, James. "The Only Game." (2001).

Włoch, Renata. 2012. 'UEFA as a New Agent of Global Governance: A Case Study of Relations between UEFA and the Polish Government against the Background of the UEFA EURO 2012.' Journal of Sport and Social Issues. DOI: $10.1177 / 0193723512467192$

\section{Authors Biographies}

Arry Bainus is Associate Professor in Department of International Relations, Universitas Padjadjaran, Indonesia. Currently, Arry Bainus serves as Vice Rector I for Academic Affairs and Student Affairs Universitas Padjadjaran. E-mail: wrl@unpad.ac.id. [Scopus ID] 57192382311.

Rusadi Kantaprawira is Professor of International Relations at Bakrie University who has expertise in Indonesian Political System. He is well known as an intellectual figure who brings systems approach and systems philosophy in studying social and political science in Indonesia. His research interest includes Systems approach, Systems Philosophy, Indonesian Political System, and Indonesian Democracy. E-mail: rusadi.kantaprawira@bakrie.ac.id

Indra Kusumawardhana is lecturer at Department of International Relations, Universitas Pertamina, Jakarta. He is Doctorate candidate at Universitas Padjadjaran, Bandung, Indonesia. [Orcid Symbol] https://orcid.org/0000-0002-8801-7506 